\title{
LINGUISTIC REPRESENTATION OF POWER IN JUDICIAL DISCOURSE
}

\author{
Margarita Zaitseva \\ Ph.D., Assistant Professor, Yaroslav Mudryi National Law University, Ukraine \\ e-mail: margozay@i.ua, orcid.org/0000-0003-4304-3644
}

\section{Summary}

This study sheds light on the terms discourse of power and power of discourse. The two concepts are closely intertwined and interdependent as manifested in the influence of power on discourse, on the selection of the linguistic means expressing that power. Such linguistic means of conveying power relations are cratologemes. Accordingly, the approach used to study cratologemes is thought to be linguocratological. From the perspective of the linguocratological approach discourse has become a vigorous resource of power. Therefore, language of discourse is of great interest an instrument of manipulation, which gives grounds to study it as an object, a process, and as a tool. During the process of investigation, the following research methods have been used: linguistic observation and analysis as well as cognitive method, pragmatic analysis method, critical discourse analysis method. These methods have allowed us to establish some of the cratologemes that are characteristic of judicial discourse. Such cratologemes have been singled out at different language levels: at the morphological level, at the lexical-semantic level, at the syntactic level.

Keywords: language means, discourse of power, power of discourse, linguistic observation, pragmatic analysis method, critical discourse analysis method, cratologemes, linguocratological approach, language levels.

\section{DOI https://doi.org/10.23856/4320}

\section{Introduction}

The cratological approach to discourse is heterogeneous and should be divided into two strands - the cratological approach itself as analysis of discourse of power and the linguocratological approach as analysis of power in discourse. Thus, for example, Norman Fairclough (1995) refers to this phenomenon as «power behind discourse» and «power in discourse», explaining the discourse of power through asymmetries of the roles of litigants and the inability to control the texts of the law in terms of their production, distribution and use; and power in discourse involves analyzing language itself and how power manifests itself through language. For example, if one person in communication uses formal means of communication (for example, «sir»), and the other one does not, then this demonstrates a relationship of power through language (Fairclough, 1995). His thoughts are developed by modern scholars: in the compendium edited by Anne Wagner and Le Cheng «Exploring Courtroom Discourse the language of power and control» (2011), there is also a distinction between power and control in the language from power and control outside the language: «Power and Control in Language» and «Power and Control behind Language» (Wagner, Cheng, 2011). The authors point out that power and its control are reflected in statements in the courtroom: «Mapping the contours of power and control in the courtroom equals an interpretation of linguistic utterances and their uses and abuses»» (Wagner, Cheng, 2011, 2). The authors refer to the discourse of power from the point of view of the parties to the proceedings: being a party to the proceedings in a given status, it must abide by the rules established by the authorities, the discourse of power becomes effective: «After the 
explorations of courtroom discourse analyses, we can admit that law is a discourse of power, and that formula opens new dimensions. Once citizens become aware of the fact that they are speakers of a specific discourse, they are indeed empowered to speak differently - to each other as well as to their respective social institutions» (Wagner, Cheng, 2011, 8).

The problem of the discourse of power seems to us worthy of mentioning because of its influence on its participants, although, in the opinion of the discursologists, this aspect should be considered in the course of political sciences, philosophy, sociology, etc. as the discourse of power manifests itself in the system of established rules in court, the distribution of roles, the consistency of answers to questions posed, the limitation of the possibility to express one's opinion in a way convenient for the party: "Legal discourse, in this context the "rules" that allow the attorney to select the topics of questions and allow the same attorney to choose not to pursue the topic even if the witness wishes to continue on that topic...» (Stygall, 1994, 20). The discourse of power thus establishes a behavioral framework for the participants of litigation, becoming a discourse for internal, narrowly limited, elitist use: «Legal language then is a wholly intra-community defined and internally determined instrument, developed, offered, and used as an instrument of its own community`s power» (Stygall, 1994, 23). It being not a linguistic prerogative, the discourse of power is certainly of interest to linguists from the perspective of communicative strategies and tactics, that are chosen by participants according to their purposes and communicative intensions within the framework of the institutional judicial discourse. This is what we are going to analyze in the article, based on the scheme proposed by W. O'Barr in his book «Linguistic Evidence: Language, Power, and Strategy in the Courtroom» (1982), in which he confronts the speech of authority and the speech of no authority: «"powerful”" versus "powerless" speech» (O 'Barr, 1982).

During the process of investigation, the following research methods have been used: linguistic observation and analysis as well as cognitive method, pragmatic analysis method, critical discourse analysis method. In the first place, we'd like to emphasise the method of discourse analysis as it helps to investigate the language not merely as a way to convey meaning of words, but a way of achieving a certain effect.

The factual material for this article was taken from the trial transcript of the Jodi Arias case (October, 2014).

\section{Linguocratological approach notion}

The discourse of power, on the one hand, and especially the political discourse, on the other, have long been the subject of intense scientific attention. In contrast to the discourse of power, the power of discourse is, in our view, a less explored concept, as well as the legal discourse unlike political discourse, for instance. So, we consider it appropriate to elaborate on this aspect, focusing on the linguocratological approach.

According to researchers in the field of cratology, «The 21 st century will be the century of humanities... Superiority in humanitarian knowledge is a way of victory in the XXI century» (Cherdantsev, Glasunov, 2015). Michel Foucault in his research The indivisibility of power and knowledge was also mentioned by Michelle Foucault in the work «Discipline and Punish. The Birth of the Prison» (1995) we mentioned earlier highlighted the indivisibility of power and knowledge. Generally speaking, the very appearance and development of the cratological interpretation of the discourse is connected with his name. The incoming power must counterbalance the achievements, the experience, the system of previous authorities for its further development, that also results in creating a discursive space for the new authority. With the linguocratological approach in mind, discourse is a powerful resource through which social actors 
and institutions are legitimised, identified and positioned. Discourse, becoming a collective speech act, "...offers certain standards of communicative-verbal behavior of individuals...» providing them with «opportunity of broad social manipulation» (Cherniavskaya, 2006, 79-80), that is, the discourse, the language of discourse, becomes a tool of manipulation, which gives grounds to study it not only as an object, a process, but also an instrument. Almost simultaneously, many discourse researchers declare it. Mention should be made of Yon Maley`s article "The Language of the Law» (2013) in which he characterises the language as a way, process and product: «Language is medium, process and product in the various arenas of the law where legal texts, spoken or written, are generated in the service of regulating social behavior» (Maley, 2013, 11), together with an American Professor G. Stygall who in her fundamental research «Trial Language. Differential discourse processing and discursive formation» (1994) deals with the discourse language as an object, process and tool: «Legal Language-As-Object, Legal Language-As-Process, Legal Language-As-Instrument» (Stygall, 1994).

In our view, a timely understanding of the discourse as a phenomenon that directly affects the essence of what is happening gives us reason to consider the discourse not only as an object, a process and an instrument, but also as a phenomenon that creates and controls reality, performing a reality-forming function.

The term biopolitics emerges from this as a modern form of crowd control, exercised through control of the individual, his body and his spirit, inevitably passing through the control of discourse: «Biopolitics, the modern form of crowd control, takes place through the control of the individual, of his body and spirit, passing therefore necessarily by discourse control» (Acselrad, 2014, 319), when a person has to consume in order to be different; produce in order to survive, acquire in order to have the illusion that he is free in his actions: "You must consume in order to be different; produce in order to survive, acquire to have the illusion of not being acquired» (Acselrad, 2014, 331). The reality of our time is that, without exaggeration, linguistics is said to be the science of science that defines and influences the way people think, the way they act. This influence of the Word even took the name of logophile, behind which the logophobia is hidden: «Behind this logofilia, which seems to prevail in our Western globalized civilization, lies an actual logofobia, represented by the institutional network that takes hold of a discourse as soon as it arises, labeling, classifying, explaining (Acselrad, 2014, 325).

Let us give some examples of the names of activities that were taken mainly from different vacancy sites: regional director for business development (approximately, but not only, director of translation agency), evangelist of native advertising (approximately, but not only, marketer), a visual artist (approximately, but not only a photographer), and so on. Under the names not just obsolete names are hidden, but a completely new look at the changed types of activities is presented, that is to say, a word changes everything.

\section{The relationship between discourse of power and the power of discourse}

The problem of the power of discourse is even how a person thinks about power and how a person talks about it. In the tradition of Western scholars, Shi-xu $(2005 ; 2007)$ argues that power implies conflict or competition between individuals, so it is associated with competition, and at worst even with domination or coercion, which is reflected in both thinking and language. Significantly, individualistic consciousness prevails. In the Eastern tradition, power is also linked to coercion, but it is the duty of the ruler to protect and paternalistically care for his subordinates, for whom he is accountable to the divine forces. In line with this, he is entrusted with the function of maintaining the divine order, monitoring the implementation of norms and 
regulations. All actions must be in accordance with universal divine law and must be fully and strictly obeyed. Subordinates are encouraged to have a collectivist consciousness.

Psychologists have long proven that the way people think and talk affects the way they think about the subject. That has given rise to emerging a separate term in Western linguistics «Damaging discourses» (Sunderland, 2004). Such discourses distort the essence of power as phenomenon, which has played a significant role in human history and must continue doing so if people are to learn to live peacefully together in an increasingly interdependent world. Human beings, as social beings, cannot fully live outside society, which, in turn, must be structured, which is achieved, inter alia, by the power expressed in laws that allow for the coordination of social life and the order of it. It is the most powerful instrument for the realization of human plans, the protection of interests, the resolution of conflict situations and the settlement of contradictions. Even the implementation of the principles of equality in society should be monitored by authorised bodies. Thus, power is present wherever there are steady associations of people: power exists in the State, in institutions, and even in the family. In the former case, it has a political function and enormous potential, constituting a powerful tool for social transformation and transformation, so that it is neither appropriate nor possible to deny power as an institution. Power, expressed in discourse and with the help of discourse, is both influential and is influenced, allowing scientists to talk about so-called interference or mediation of discourse to create a positive image of power at the level of mental representation. It is for this reason that the proponents of the peace-building and peace-keeping theory are trying to formulate alternative ways of representing power at the level of consciousness and verbal representation. These efforts are seen as an attempt to intervene or mediate a discourse, that is, to intervene in a discourse to change social reality by changing the discourses that help to construe this reality: «These efforts can be understood as a project of discourse intervention - an effort to change our social reality by altering the discourses that help constitute that reality. To date, this project is still in a nascent stage and thus remains an important yet incomplete intervention in the Western liberal culture of conflict» (Karlberg, 2005, 1).

With the help of language and in language, philosophers, sociologists, historians, psychologists, politicians and, of course, lawyers whose activities are limited to legal techniques, the so-called language game, which represents both the very rules of the game and the art of wielding those rules. According to lawyers, meaning without text does not exist, it appears after reading the text, in other words, meaning is «created by the interpreter of legal text» (Alexandrov, 2007). Various types of legal discourse can coexist or oppose in litigation, and then the judge is to resolve the conflict of interpretations, assigning to one of them the status of the true, in other words, «...legal is the linguistic, textual plus powerful» as was fairly noted by A. S. Alexandrov (2007), a discursive. A lawyer takes a direct participation in this process, so he is to know words and techniques, helping to bring these words to the judge. By and large, he is as successful as he is with his words. It is obvious that a lawyer must possess a «powerful speech», which causes respect and influences the recipients, especially the members of the jury, since the English-speaking countries have an adversarial court system. and even less the judges, whose decision must be valid and enforceable. And even more so for judges, whose decisions must be weighty and achievable.

The discourse of power, intertwined with the power of discourse, exhibits signs of coerciveness that lead to the use of certain language means (cratologemes).

\section{Cratologemes in court discourse}

Based on the American Heritage Dictionary, we understand coerciveness in this research as «to dominate, restrain, or control by force». So, let`s analyse the language means 
that express coerciveness in English courtroom discourse on the example of the Jodi Arias` Trial (2014).

The defense lawyer Ms. J. Willmott together with the prosecutor Mr. J. Martinez conducts her direct examination. The judge Sherry K. Stephens plays a supervisory role in the process.

It may be observed that the prosecutor uses nouns:

(1) Objection. Relevance (Jodi Arias`Trial, 6)

(2) Objection. Lack of foundation. Which time? (ibid, 7)

(3) Objection. Speculation. Lack of foundation (ibid, 25)

(4) Lack of foundation, dates (ibid, 47)

(5) Objection. Speculation. Lack of foundation. How? (ibid, 63)

(6) Objection. Lack of foundation to my understanding (ibid, 78)

(7) Same objection. Lack of foundation (ibid, 79)

(8) Objection. Foundation. They went to Bobbie`s house (ibid, 79)

(9) Objection. Leading (ibid, 102).

Such a linguistic device as nominalisation is widely used by the prosecutor. Nominalisation realises both persuasive and oppressive functions as the information due to nominalisation appears more objective and factual (Thompson, 2014, 250), and, as a result, more influential. When it is becomes clear that such strategy is insufficient he engages other means that extend nominalisation:

(1) Judge, she keeps trailing off and I am having difficulty hearing her (Jodi Arias` Trial, 48)

(2) I have no objection. I am really having a hard time hearing her (ibid, 105).

(3) Well, I respectfully disagree. We have a right to know when these photographs were taken and if we do not know, then the foundation has not been laid (ibid, 125).

The judge takes a different tactic to create coercive discourse. He exploits fully the potential of elliptical sentences. While from a grammatical point of view they may be seen as structurally incomplete, from the point of view of the pragmatic function, they fully fulfil it, as they acquire additional expressive power due to their shortened structure:

(1) Overruled (Jodi Arias `Trial, 6, 63, 99, 100, 102, 113, 128, 130)

(2) Sustained (ibid, 7, 26, 63, 79, 98, 113, 124)

The brevity of the utterances helps the judge to be impersonal, more objective and impartial in contrast to the prosecutor, consequently.

Finally, as cratologeme we can distinguish the modal verb may that expresses more formal permission:

(1) You may proceed (Jodi Arias` Trial, 4)

(2) The defense may call its first witness (ibid, 4)

(3) You may (ibid, 18)

(4) Yes, you may step down (ibid, 81)

(5) Miss Willmott, you may continue (ibid, 81)

Also, we should like to stress that the verb «may» helps to avoid ambiguity unlike the modal verb «can».

\section{Conclusions}

To sum up, we'd like to emphasise that from the perspective of the linguocratological approach discourse has become a vigorous resource of power. Therefore, language of discourse is of great interest an instrument of manipulation, which gives grounds to study it as an object, 
a process, and as a tool. However, in our opinion, discourse is not only a tool that influences reality, but it also creates and controls that reality. We can observe a two-way process whereby discourse of power determines and influences the way of thinking and speech behaviour of individuals and at the same time discourse power manifests itself in the existence of specific linguistic means - cratologems.

As the study of the factual material has shown, the modal verb may acts as a cratologem in judicial discourse at the morphological level, nominalisation - at the lexical-semantic level, elliptical sentences - at the syntactic level.

The topic of the article seems forward-looking, as it would be interesting to investigate cratologemes and their linguistic expression in different types of judicial discourse.

\section{References}

Acselrad, M. (2014). Biopolitics, discursive order and communication. Intercom: Revista Brasileira de Ciências da Comunicação, 37(2). https://doi.org/10.1590/1809-5844201414

Aleksandrov, A. C. (2007). Yuridicheskaya tehnika - sudebnaya lingvistika - grammatika prava [Legal Technique - Forensic Linguistics - Grammar of Law]. Moscow: Yurist. [in Russian] Cherdantsev, V., Glazunov O. (2015). Prikladnaya kratologiya. Nauka o vlasti [Applied Cratology. The Science of Power]. Moscow: Probel. [in Russian]

Chernyavskaya, E. V. (2006). Diskurs vlasti i vlast diskursa: problemyi rechevogo vozdeystviya [Power Discourse and the Power of Discourse: Problems of Speech Effects]. Moscow: Flinta. [in Russian]

Fairclough, N. (1995). Critical discourse analysis: papers in the critical study of language. London and New York: Longman Group Limited.

Foucault, M. (1995). Discipline and punish: the birth of the prison. New York : Vintage Books Jodi Arias`Trial (2014) https://blogs.findlaw.com/courtside/2015/01/jodi-arias-secret- testimony-transcripts-released.html

Karlberg, M. (2005). The power of discourse and the discourse of power: pursuing peace through discourse intervention. In International Journal of Peace Studies, Volume 10, Number 1. http://www.gmu.edu/programs/icar/ijps/vol10_1/Karlberg_101IJPS.pdf

Maley, Y. (2013). The Language of the Law. In Language and the Law. London; New York: Routledge.

O'Barr, W. M. (1982). Linguistic evidence: Language, power, and strategy in the courtroom. New York: Academic Press.

Shi-xu (2005). A Cultural Approach to Discourse. New York: Palgrave Macmillan.

Shi-xu (2007). Discourse as Cultural Struggle. Hong Kong: Hong Kong University Press

Stygall, G. (1994). Trial language: Differential discourse processing and discursive formation. Amsterdam: John Benjamins

Sunderland J. (2004). 'Damaging Discourses' and Intervention in Discourse. In: Gendered Discourses. London: Palgrave Macmillan https://doi.org/10.1057/9780230505582_9 Thompson, G. (2014). Introducing functional grammar. London; New York: Routledge.

Wagner, A., Cheng, Le (2011). Language, Power and Control in Courtroom Discourse Exploring courtroom discourse: the language of power and control. - (law, language and communication). Ashgate publishing Company

DISCIPLINE AND PUNISH The Birth of the Prison 1995353 p. https://monoskop.org/ images/4/43/Foucault_Michel_Discipline_and_Punish_The_Birth_of_the_Prison_1977_ 1995.pdf 